\title{
Training and Performance: A Sign from Saudi Service Organizations
}

\author{
Bader M. A. Almohaimmeed ${ }^{1}$ \\ ${ }^{1}$ Business Administration Department, College of Business and Economics (CBE), Qassim University, Buraydah, \\ Saudi Arabia \\ Correspondence: Bader M. A. Almohaimmeed, Business Administration Department, College of Business and \\ Economics (CBE), Qassim University, Buraydah, Saudi Arabia. \\ Received: September 11, 2017 \\ Accepted: October 5, 2017 \\ Online Published: October 18, 2017 \\ doi:10.5539/ibr.v10n11p148 \\ URL: https://doi.org/10.5539/ibr.v10n11p148
}

\begin{abstract}
The aim of this study is to explore the effect of training on organizational performance. Training techniques were categorized into two types: behavioural training techniques (on-the-job training) and cognitive training techniques (off-the-job training). Three behavioural techniques were selected - monitoring, coaching, and job rotation - and three cognitive techniques - role playing, lectures, and computer-based training. Training as an independent construct was measured based on these behavioural and cognitive techniques. On the other hand, organizational performance was measured based on subjective items related to the operational dimensions of organizations' performance. A questionnaire-based survey was used to collect data from a sample consisting of 600 employees working at service organizations in Saudi Arabia. Of the questionnaires distributed to the sample, 478 were returned complete and valid for the analysis process. The Statistical Package of Social Sciences (SPSS) version 20 was used to analyse the collected data. The findings of the study confirmed that both behavioural techniques of training were significantly and positively related to organizational performance. In fact, the results identified job rotation as a main practice of on-the-job training techniques that lead to improved organizational performance. There is a statistically significant influence of other dimensions, such as coaching, monitoring, role playing, lectures, and computer-based training, on organizational performance. Despite the positive and direct impact of on-the-job training and off-the-job training on the dependent variable, organizational performance, onthe-job training has a larger impact on this construct. The results are presented and discussed, and recommendations, limitations, and future research directions are provided.
\end{abstract}

Keywords: training, on-the-job training, off-the-job training, organizational performance.

\section{Introduction}

Organizations face many challenges, including increased competition under globalization. Therefore, organizations are required to consider human resource management practices in general and training in particular. Training has been defined as providing employees with knowledge, skills, and abilities that enable them to carry out organizational activities efficiently and effectively (Hanaysha, 2016). As a result, training improves organizational performance (Khan et al., 2011). In terms of the importance of training, some studies have shown that this concept plays an important role in improving the efficiency and effectiveness of staff in particular and the organization as a whole. The reason for the role of training in improving staff performance is that training increases the knowledge, skills, and abilities of the employees. Ultimately, improved staff performance improves the performance of the organization (Khan et al., 2011).

The relationship between training and performance remains controversial among researchers. Some studies have confirmed the direct impact of training on performance, while others have pointed out that training has no significant relationship with performance (Aragon et al., 2014). In contrast, numerous studies have found that training significantly and positively affects organizational performance (Sherwani \& Mohammed, 2015). Of the respondents who participated in Kum et al.'s (2014) study, about 70 per cent agreed that training programmes enhanced their performance. In the context of public universities, Talpur et al. (2016) found a significant as well as positive effect of training on organizational performance. Elnaga and Imran (2013) confirmed that training has a positive impact on employee performance. Shaheen et al. (2013) studied the mediating role of employee performance in the relationship between employees' training and organizational performance. Their results revealed a positive relation between these two constructs. Based on their results obtained from examining the relationship between the training and the organizational performance of five telecom companies, Sultana et al. 
(2012) regarded training as a vital element in the process of organizational performance enhancement.

The present study aims to verify the impact of training on organizational performance using a sample of companies operating in the service sector. The main contribution of the current study stems from the identification of the actual role of training in improving organizational performance in the business environment of Saudi companies. Some studies have confirmed that solving organizational performance problems does not depend solely on training. Sometimes training does not improve performance, because the staff members in fact do not need training (Milhem et al., 2014). Therefore, the present study aims to investigate the actual relationship between training and performance, especially since training is a costly process. The study comprises two independent variables, which are on-the-job training, measured by monitoring, coaching, and job rotation, and off-the-job training, evaluated by role playing, lectures, and computer-based training. The study includes one dependent variable, which is organizational performance.

\section{Literature Review and Hypothesis Development}

There is almost a consensus among researchers that the aim of training employees is to provide them with skills, knowledge, and capabilities that can be used for the implementation of work activities as well as to provide opportunities for their development (Hanaysha, 2016). The definitions provided in Sherwani and Mohammed's (2015) study confirmed that training, as a human resource management practice, is a good way to improve employees' knowledge, skills, and development opportunities. Citing Nel et al. (2004), Kum et al. (2014) argued that training results in a significant change in employees' behaviour, reduces defects and failures of projects, and increases the abilities of the employees to progress and perform more projects. Khan et al. (2017) and Talpur et al. (2016) added that employee training and development programmes lead to enhanced job performance. Goldstein and Ford (2002, cited in Aguinis \& Kraiger, 2009) defined training as a systematic learning and development approach used to enhance the effectiveness of individuals, groups, and organizations as a whole.

In fact, studying the relationship between training methods and organizational performance is very important, since the confirmation of the hypotheses helps organizations to acquire one of the most effective tools required to survive, gain a competitive advantage, enhance the quality of work life, and improve the capabilities of their employees (Kulkarni, 2013). Kulkarni divided training types into two types, on-the-job training and off-the-job training, and reported some examples of on-the-job training methods - step-by-step training, job rotation, job instructions, committee assignment, coaching, and internship training - and off-the-job training methods - role playing, workshops, lectures, case studies, conferences, computer modelling, and experiential as well as stimulation exercises.

In the same context, Falola et al. (2014) classified training into two main types: behavioural and cognitive training. According to them, behavioural training refers to on-the-job training, while cognitive training refers to off-the-job training. Malaolu and Ogbuabor (2013) defined on-the-job training as a training technique used to equip employees with specific skills while they are on the job. They defined off-the-job training as a training technique provided in educational institutions, which lasts for a specified period. For the current study, three behavioural techniques of on-the-job training were selected, which were monitoring, coaching and job rotation, and three cognitive techniques of off-the-job training, which were role playing, lectures, and computer-based training (Falola et al., 2014; Kulkarni, 2013; Malaolu \& Ogbuabor, 2013).

Concerning the relationship between training and performance, mixed results were drawn from previous studies. Numerous studies have stressed the importance of the role of training in improving organizational performance. Vinesh (2014) regarded training as a significant tool that results in enhanced employee performance and satisfaction and increased productivity and equality of goods and services, in addition to decreased efforts of supervision and costs.

Sherwani and Mohammed (2015) found a positive effect of training programme success on employees' outcomes, such as productivity, capability to solve work-related problems, and performance. Percival et al. (2013) highlighted the significance of investment in training to maintain employees' productivity. Using a sample consisting of employees working in banks in Nigeria, Umar et al. (2013) used five variables to measure training and development in those banks, which were the organization's commitment to the training and development of employees, types of training employed, frequency of training, performance-based rewards provided during training sessions, and modern training facilities. Their results accepted the hypotheses that organizational commitment, frequency of training, and performance-based rewards have a significant impact on organizational performance. On the other hand, the types of training and modern training facilities have no significant effects on organizational performance. One study conducted in the banking sector in India by Bhat (2013) found a positive influence of training on employee performance. 
Using a sample of the employees working at a Lebanese industrial company, Tangoukian et al. (2016) conducted a study to examine the advantages and pitfalls of training and found that most of the departments in the company implement both internal and external training practices, despite the fact that employees prefer external training to internal training. In their review of research, the effect of training on organizational outcomes, such as human resource outcomes, performance outcomes, financial outcomes, and stock outcomes, Tharenou et al. (2007) found that the strongest correlation was between training and organizational outco mes, such as organizational performance. Saks and Burke-Smalley (2014) questioned the relationship between training transfer and organizational performance using a sample of training participants in a training institution in Canada. Interestingly, their findings suggested that on-the-job training has the strongest relationship with both training transfer and organizational performance. The results of Falola et al.'s (2014) study confirmed that both behavioural and cognitive aspects of training result in increased performance. It should be noted here that some studies have dealt with training in terms of strategies, policies, or types rather than as a general construct. For example, Khan et al. (2011) studied the relationship between training and performance by focusing on workplace training or so-called on-the-job training, training style, and training design. In terms of the relationship between on-the-job training and organizational performance, the study showed a significant effect of on-the-job training on performance. Table 1 includes examples of the results of some previous studies.

Table 1. Impact of training methods or types on organizational performance in the literature

\begin{tabular}{lcc}
\hline \multicolumn{1}{c}{ Authors } & Positive impact & Negative impact \\
\hline Tharenou et al. (2007) & $\checkmark$ & - \\
Khan et al. (2011) & $\checkmark$ & - \\
Bhat (2013) & $\checkmark$ & - \\
Percival et al. (2013) & $\checkmark$ & - \\
Umar et al. (2013) & $\checkmark$ & - \\
Elnaga and Imran (2013) & - & $\checkmark$ \\
Umar et al. (2013) & - & - \\
Aragon et al. (2014) & $\checkmark$ & - \\
Saks and Burke-Smalley (2014) & $\checkmark$ & - \\
Sherwani and Mohammed (2015) & $\checkmark$ & - \\
Hanaysha (2016) & $\checkmark$ & - \\
Talpur et al. (2016) & $\checkmark$ & \\
Khan et al. (2017) & $\checkmark$ & \\
\hline
\end{tabular}

On the basis of the above-mentioned literature and following previous works, such as Falola et al. (2014), Khan et al. (2011), Kulkarni (2013), Malaolu and Ogbuabor (2013), and Saks and Burke-Smalley (2014), the current study classified training into two types: on-the-job training (monitoring, coaching, and job rotation) and off-the-job training (role playing, classroom lectures, and computer-based training). Consequently, two hypotheses were suggested:_

$\mathrm{H}_{1}$ : On-the-job training techniques are positively and significantly related to organizational performance.

$\mathrm{H}_{2}$ : Off-the-job training techniques are positively and significantly related to organizational performance.

\section{Methodology}

\subsection{The Conceptual Model of the Study}

Figure 1 displays the conceptual model of the study. The figure shows two independent variables - on-the-job training and off-the-job training - and one dependent variable - organizational performance. 


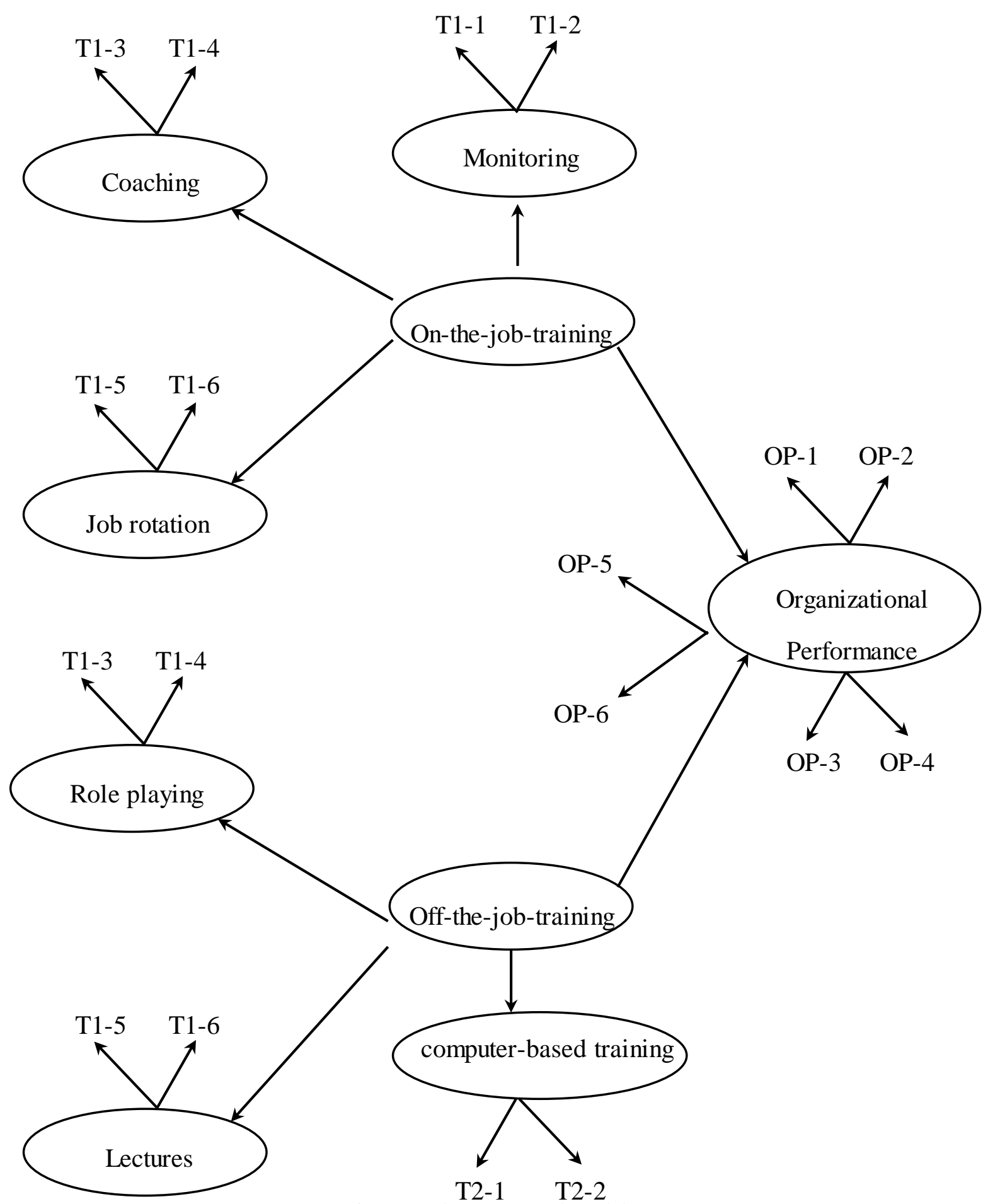

Figure 1. The conceptual model

\subsection{The Sample of the Study and Data Collection}

The sample of the current study consisted of 600 employees of service organizations in the capital city, Riyadh. A questionnaire designed on the basis of Likert five-point scales (1: strongly disagree, 5: strongly agree) was used to collect the required data from the sample members. It was composed of three measures adopted to evaluate the study constructs: on-the-job training, off-the-job training, and organizational performance. The questionnaire was distributed via e-mail to the employees. A total of 478 questionnaires were returned complete and valid for the statistical analysis. 


\subsection{Measures}

Training dimensions comprised two techniques of training, behavioural and cognitive techniques. The behavioural techniques were measured using the three sub-dimensions of monitoring, coaching, and job rotation, while the cognitive techniques were assessed using the three sub-dimensions of role playing, lectures, and computer-based training. Twelve items were adopted from previous studies (Falola et al., 2014; Malaolu \& Ogbuabor, 2013) to measure training techniques, with six items for each dimension. An example of an on-the-job training item is "my company deems monitoring as a basic part of the on-the-job training adopted". Organizational performance was measured using six items concerning the quality of service provided, development of new services, and increased market share (Shaheen et al., 2013). One of the items used to measure OP was "my company achieved an increased market share from 2014 to 2016". Table 2 shows the components of the questionnaire used in this study.

Table 2. The components of the questionnaire used in the current study

\begin{tabular}{|c|c|c|c|}
\hline Variables & Dimensions & Sub-dimensions & No. of items \\
\hline & \multirow{4}{*}{ On-the-job-training } & Monitoring & 2 \\
\hline \multirow[t]{3}{*}{ Behavioral techniques } & & Coaching & 2 \\
\hline & & Job rotation & 2 \\
\hline & & Role playing & 2 \\
\hline \multirow[t]{3}{*}{ Cognitive techniques } & \multirow[t]{2}{*}{ Off-the-job-training } & Lectures & 2 \\
\hline & & Computer-based training & 2 \\
\hline & Quality of service & - & 2 \\
\hline \multirow[t]{2}{*}{$\mathrm{OP}$} & New services & - & 2 \\
\hline & Market share & - & 2 \\
\hline
\end{tabular}

\section{Results}

Means and standard deviations (SDs) were calculated for all the items included in the questionnaire. The results shown in Table 3 indicated that the mean values of items were above 3.60. Moreover, the results of factor loadings in the same table pointed out strong loadings of all the items consistent with the suggested threshold point 0.6 (Talpur et al., 2016). The table also shows the results of the average variance explained (AVE), Cronbach's alpha, and composite reliability. It was concluded that the AVE values for the study constructs were above $0.5(0.785,0.847$, and 0.794$)$ and the Cronbach's alpha values ranged from 0.77 to 0.81 (all the values were above 0.7 ).

Table 3. Results of means, SDs, AVE, loadings, Cronbach's alpha, and composite reliability

\begin{tabular}{|c|c|c|c|c|c|c|c|}
\hline Constructs & Items & Mean & SD & Loading & AVE & $\alpha$ & CR \\
\hline \multirow{7}{*}{ On-the-job-training } & $\mathrm{T} 1-1$ & 4.29 & 1.03 & 0.671 & \multirow{7}{*}{0.785} & \multirow{7}{*}{0.779} & \multirow{7}{*}{0.855} \\
\hline & T1-2 & 3.84 & 1.21 & 0.711 & & & \\
\hline & $\mathrm{T} 1-3$ & 3.86 & 0.98 & 0.821 & & & \\
\hline & T1-4 & 4.54 & 0.79 & 0.742 & & & \\
\hline & T1-5 & 4.12 & 1.00 & 0.799 & & & \\
\hline & T1-6 & 4.00 & 0.98 & 0.880 & & & \\
\hline & Total & 4.11 & 0.88 & - & & & \\
\hline \multirow{7}{*}{ Off-the-job-training } & T2-1 & 3.71 & 0.87 & 0.771 & \multirow{7}{*}{0.847} & \multirow{7}{*}{0.844} & \multirow{7}{*}{0.793} \\
\hline & $\mathrm{T} 2-2$ & 3.89 & 0.77 & 0.840 & & & \\
\hline & $\mathrm{T} 2-3$ & 3.76 & 0.69 & 0.800 & & & \\
\hline & $\mathrm{T} 2-4$ & 4.16 & 0.86 & 0.753 & & & \\
\hline & $\mathrm{T} 2-5$ & 2.78 & 1.04 & 0.951 & & & \\
\hline & $\mathrm{T} 2-6$ & 1.99 & 0.90 & 0.886 & & & \\
\hline & Total & 3.38 & 0.73 & - & & & \\
\hline \multirow{7}{*}{ OP } & OP-1 & 4.55 & 1.12 & 0.759 & \multirow{7}{*}{0.794} & \multirow{7}{*}{0.867} & \multirow{7}{*}{0.801} \\
\hline & OP-2 & 3.88 & 0.59 & 0.957 & & & \\
\hline & OP-3 & 4.78 & 0.82 & 0.695 & & & \\
\hline & OP-4 & 4.91 & 0.74 & 0.751 & & & \\
\hline & OP-5 & 3.99 & 0.79 & 0.863 & & & \\
\hline & OP-6 & 3.87 & 0.88 & 0.831 & & & \\
\hline & Total & 4.33 & 0.971 & - & & & \\
\hline
\end{tabular}

According to Paat and Rumokoy (2015), values of Cronbach's alpha equal to 0.7 indicate acceptable data reliability, while values more than 0.7 represent an indicator of good reliability. The composite reliability (CR) values of the study variables, which ranged from 0.877 to 0.911 , are considered to be acceptable, since all the values were above 0.7 . It has been proved that the total mean value of on-the-job training dimensions $(M=4.11$, $\mathrm{SD}=0.88)$ is greater than the total mean value of the off-the-job training dimensions $(\mathrm{M}=3.38, \mathrm{SD}=0.73)$. 


\subsection{Correlation Analysis}

Pearson coefficients for training techniques as well as organizational performance were calculated to investigate the degree of correlation between each pair of these variables. The results displayed in Table 4 point out positive correlations between on-the-job training and off-the-job training $(r=0.381, \mathrm{P}<0.05)$, between on-the-job training and organizational performance $(\mathrm{r}=0.401, \mathrm{P}<0.05)$, and between off-the-job training and organizational performance $(\mathrm{r}=0.377, \mathrm{P}<0.05)$.

Table 4. Pearson's correlation matrix

\begin{tabular}{cccc}
\hline Variables & T1 & T2 & OP \\
\hline T1 & - & & \\
T2 & $0.381^{*}$ & $0.377^{*}$ & - \\
OP & $0.401^{*}$ & 0.07 performance & \\
\hline
\end{tabular}

T1: on-the-job training, T2: off-the-job training, OP: organizational performance

* Correlation is significant at the 0.05 level (2-tailed).

\subsection{Structural Equation Modelling (SEM)}

The main aim of the structural model is to explore the degree to which the hypothesized model of the study is fit (Al-Harthy, 2017). For the current study, it was hypothesized that on-the-job training and off-the-job training have an impact on organizational performance. The findings of the SE model related to the fit indices shown in Table 5 confirmed the acceptable values of these indices.

Table 5. The results of SEM

\begin{tabular}{ccccc}
\hline Index & Value & Result & Interpretation & Reference \\
\hline$\chi^{2}$ & 2.63 & Accepted & $<3$ & Hair et al. (1998) \\
GFI & 0.97 & Accepted & $>0.95$ & Engel and Moosbrugger (2003) \\
RMSEA & 0.043 & Accepted & $\leq 0.09$ & Iacobucci (2010) \\
\hline
\end{tabular}




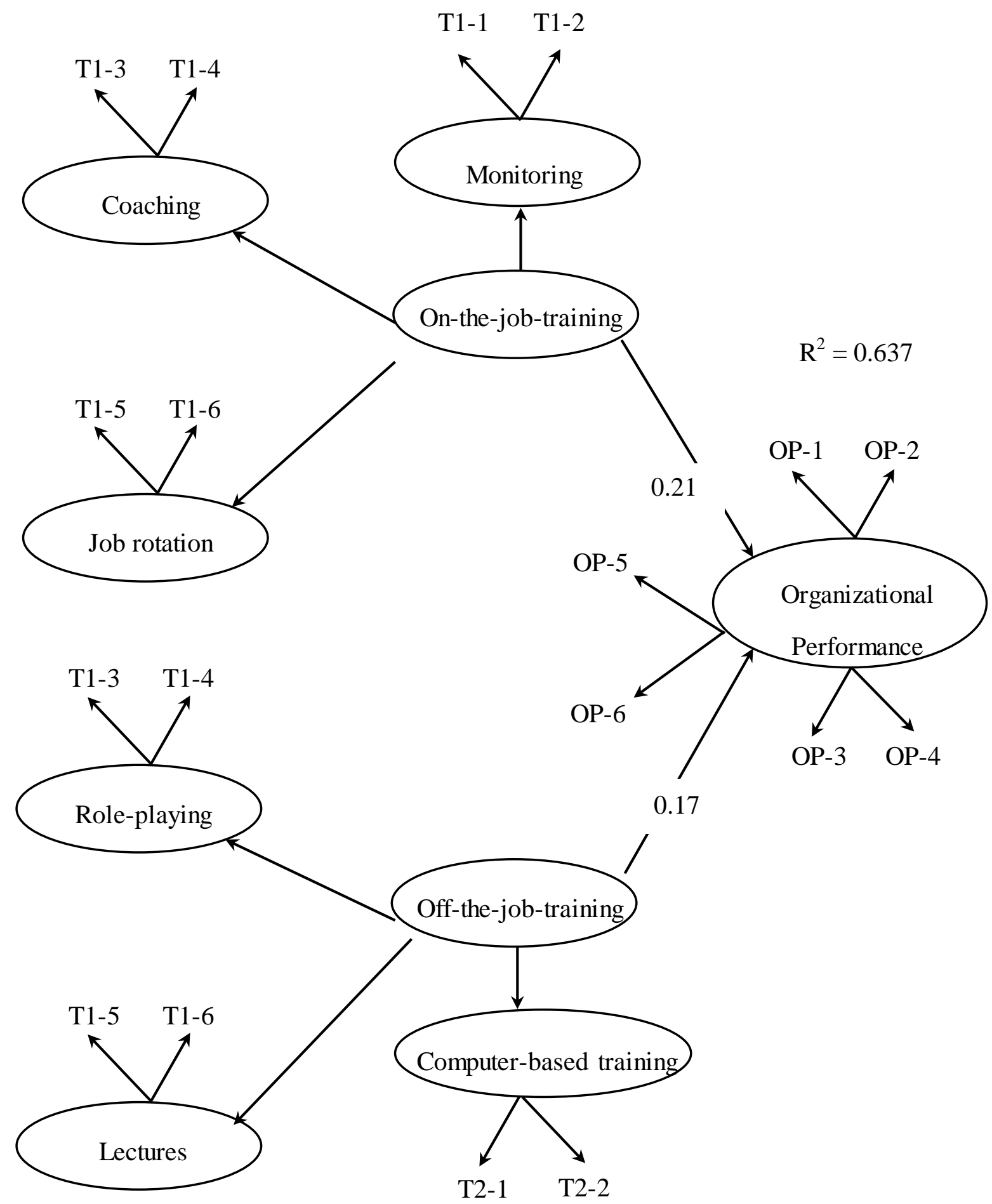

Figure 1. The conceptual model

The results of the data collected from the members of the study sample supported the hypotheses of the study. It was concluded that on-the-job training and off-the-job training are both related to $\mathrm{OP}(\beta=0.21, \mathrm{P}=0.003$ and $\beta$ $=0.17, \mathrm{P}=0.010$, respectively). However, the most valuable influence on OP was from the on-job training technique. Table 6 shows a summary of the results.

Table 6. A summary of the study results

\begin{tabular}{cllllll}
\hline So. & \multicolumn{1}{c}{ Suggested path } & & & $\beta$ & $\mathrm{P}$ & Result \\
\hline $\mathrm{H}_{1}$ & On-the-job training techniques & $\longrightarrow$ & OP & 0.21 & 0.003 & Accepted \\
$\mathrm{H}_{2}$ & Off-the-job training techniques & $\longrightarrow$ & OP & 0.17 & 0.010 & Accepted \\
\hline
\end{tabular}




\section{Discussion and Conclusion}

The aim of the current study was to investigate the impact of training techniques on the organizational performance of organizations working in the service sector. Training techniques were categorized into two types: behavioural-based techniques (monitoring, coaching, and job rotation) and cognitive-based techniques (role-playing, lectures, and computer-based training). The results confirmed that both techniques of training investigated in the current study are significantly and positively related to the organizational performance of service organizations. Job rotation was the most significant variable with the strongest effect on organizational performance, followed by coaching and monitoring. On the other hand, role playing, as one of the cognitive training techniques, was the most important variable in terms of its influence on organizational performance, followed by computer-based training. Interestingly, lectures, as one practice of off-the-job-training, had no significant impact on the organizational performance. The results of the current study echo those of numerous previous studies, such as Paat and Rumokoy (2015). According to them, this type of training is considered to be a specific teaching technique within the organizational policy and related to the knowledge and skills required to perform specific jobs. Tharenou et al. (2007) conducted a review of research on training and organizational outcomes, such as (1) human resource outcomes, namely employee turnover, a low level of absenteeism, high job performance, and motivation; (2) organizational performance outcomes, specifically quality, service, and productivity; (3) financial outcomes, that is, return on investment, return on assets, and profit; and (4) stock market outcomes, namely stock value and shareholder value. Their results indicated that the effect of training on organizational performance and human resource outcomes is greater than the effect of training on financial outcomes. Despite the positive effect of training on organizational performance, it is in fact a small effect. The authors explained this as being due to other factors that have an influence on organizational performance. Similar results revealed by previous studies that match the same constructs of training used in the current study are very scarce. Most studies that have investigated the relationship between training and organizational performance have conceptualized training as a whole construct. For the current study, training was categorized into two techniques: on-the-job training and off-the-job training. Each of these constructs was divided into three sub-categories. The conceptualization of training in this way in the present study represents its main contribution. In general, the results obtained by the study were similar to the results of many other studies in the same context, which pointed out a significant as well as positive influence of training on organizational performance (Elnaga \& Imran, 2013; Falola et al., 2014; Khan et al., 2011, 2017; Kum et al., 2014; Percival et al., 2013; Saks \& Burke-Smalley, 2014; Shaheen et al., 2013; Sherwani \& Mohammed, 2015; Sultana et al., 2012; Talpur et al., 2016; Tangoukian et al., 2016; Umar et al., 2013).

\section{Recommendations, Limitations, and Future Research}

On the basis of the above-mentioned findings, organizations are required to pay more attention to training techniques. In fact, the findings of the study revealed that both techniques examined in the study (on-the-job training and off-the-job training) have a significant impact on organizational performance. However, the effect of on-the-job training techniques on organizational performance is greater than the effect of off-the-job training techniques. Therefore, more attention should be paid to training techniques such as monitoring, coaching, and, particularly, job rotation.

On the other hand, researchers are required to study the influence of different variables related to training on organizational performance using samples from different sectors. It is worth mentioning here that the relationship between training practices and organizational performance is restricted to other variables that mediate the relationship between these two variables, such as employees' job involvement (Sultana et al., 2012).

The findings of the present study are limited to organizations operating in the service industry. Concerning the variables studied in this study, training was assessed using two techniques: behavioural and cognitive techniques. Other dimensions of training facilities should be considered in new studies, such as organizations' commitment to the training and development of employees, the frequency of training, and performance-based rewards provided during training sessions. The organizational performance was measured using factors related to the operational dimensions of performance; hence, additional dimensions related to the financial aspects of organizational performance are required to ensure a comprehensive as well as an effective measurement of this variable. Therefore, further studies are needed to explore the relationship between training and performance using a larger sample of organizations and organizations from other sectors.

\section{References}

Aguinis, H., \& Kraiger, K. (2009). Benefits of training and de velopment for individuals and teams, organizations, and society. Annual Review of Psychology, 60, 451-474. 
https://doi.org/10.1146/annurev.psych.60.110707.163505

Al-Harthy, W. (2017). Principles and Practice of Educational Management among Private Colleges in Muscat City, Sultanate of Oman. Journal of Basic and Environmental Sciences, 4(2017), 34-51.

Aragon, M., Jiménez, D., \& Valle, R. (2014). Training and performance: The mediating role of organizational learning. Business Research Quarterly, 17, 161-173. https://doi.org/10.1016/j.cede.2013.05.003

Bhat, Z. (2013). Impact of training on employee performance: A study of retail banking sector in India. Indian Journal of Applied Research, 3(6), 292-293. https://doi.org/10.15373/2249555X/JUNE2013/97

Elnaga, A., \& Imran, A. (2013). The Effect of Training on Employee Performance. European Journal of Business and Management, 5(4), 137-147.

Engel, K., \& Moosbrugger, H. (2003). Evaluating the fit of structural equation models: tests of significance and descriptive goodness-of-fit measures. Methods of Psychological Research Online, 8(2), 23-74.

Falola, H., Osibanjo, A., \& Ojo, S. (2014). Effectiveness of training and development on employees' performance and organization competitiveness in the Nigerian banking industry, Bulletin of the Transilvania University of Braşov, Series V: Economic Sciences, 7(56), No. 1, 161-170.

Goldstein, I. L., \& Ford, J. K. (2002).Training in Organizations. $4^{\text {th }}$ ed., Belmont, CA: Wadsworth.

Hair, J. Jr., Anderson, R., Tatham, R., \& Black, W. (1998). Multivariate Data Analysis, $5^{\text {th }}$ ed., New Jersey, Prentice-Hall, USA.

Hanaysha, J. (2016). Examining the effects of employee empowerment, teamwork, and employee training on organizational commitment. Fifth International Conference on Leadership, Technology, Innovation and Business Management. Procedia-Social and Behavioral Sciences, 229, 298-306. https://doi.org/10.1016/j.sbspro.2016.07.140

Iacobucci, D. (2010). Structural equations modeling: Fit Indices, sample size, and advanced topics. Journal of Consumer Psychology, 20, 90-98. https://doi.org/10.1016/j.jcps.2009.09.003

Khan, R., Khan, F., \& Khan, M. (2011). Impact of training and de velopment on organizational performance. Global Journal of Management and Business Research, 11(7), version 1, 62-68.

Khan, U., Haleem, R., \& Kanwal, S. (2017). Effect of training and de velopment on employee attitude: A study on Karachi. Center for Promoting Education and Research (CPER)-USA, 3(4), 43-50.

Kulkarni, P. (2013). A literature review on training, development, and quality of work life. International Refereed Research Journal, IV(2), 136-143.

Kum, F., Cowden, R., \& Karodia, A. (2014). The impact of training and development on employee performance: A case study of Escon Consulting. Singaporean Journal of Business Economics and Management Studies, 3(3), 72-105. https://doi.org/10.12816/0010945

Malaolu, V., \& Ogbuabor, J. (2013). Training and manpower development, employee productivity and organizational performance in Nigeria: An empirical investigation. International Journal of Advances in Management and Economics, 2(5), 163-177.

Milhem, W., Abushamsieh, H., \& Aróstegui, M. (2014). Training Strategies, Theories and Types. Journal of Accounting - Business \& Management, 21(1), 12-26.

Nel, P., Gerber, P., van Dyk, P., Haasbroek, D., Schultz, H., Sono, T., \& Werner, A. (2004). Human resources management. $6^{\text {th }}$ Ed., South Africa: Oxford University Press.

Paat, G., \& Rumokoy, F. (2015). The comparative analysis of employee performance before and after training at Bank Indonesia in Manado. Journal Riset Ekonomi, Manajemen, Bisnis Dan Akuntansi, 3(3), 189-198.

Percival, J., Cozzarin, B. and Formaneck, S. (2013). Return on investment for workplace training: The Canadian experience. International Journal of Training and Development, 17(1), 20-32. https://doi.org/10.1111/ijtd.12002

Saks, A., \& Burke-Smalley, L. (2014). Is transfer of training related to firm performance? International Journal of Training and Development, 18(2), 104-115. https://doi.org/10.1111/ijtd.12029

Shaheen, A., Naqvi, S., \& Khan, M. (2013). Employees training and organizational performance: Mediation by employees' performance. Interdisciplinary Journal of Contemporary Business Research, 5(4), 490-503.

Sherwani, K., \& Mohammed, N. (2015). An analysis of training and employee performance: Acase study in a 
telecommunication company in Erbil. International Journal of Social Sciences \& Educational Studies, 2(2), 74-82.

Sultana, F., Irum, S., Ahmed, K., \& Mehmood, N. (2012). Impact of training on employee performance: A study of telecommunication sector in Pakistan. Interdisciplinary Journal of Contemporary Business Research, $4(6), 464-661$.

Talpur, Q., Jhatial, A., Murtaza1, G., Memon, Z., \& Bukhari, H. (2016). The Relationship between Employees' Training and their Performance in Public Universities in Pakistan. NICE Research Journal, 46-59.

Tangoukian, A., Abo-Hamad, J., \& Menassa, E. (2016). Advantages and pitfalls of training in a Lebanese manufacturing company: A qualitative approach. The MENA Journal of Business Case Studies, 2016(866941), 1-10. https://doi.org/10.5171/2016.866941

Tharenou, P., Saks, A., \& Moore, C. (2007). A review and critique of research on training and organizational-level outcomes. Human Resource Management Review, 17, 251-273. https://doi.org/10.1016/j.hrmr.2007.07.004

Umar, G., Emmanuel, T., \& Oluseyi, A. (2013). Empirical study of training and development as a tool for organizational performance: Case study of selected banks in Nigeria. Kuwait Chapter of Arabian Journal of Business and Management Review, 2(10), 78-87. https://doi.org/10.12816/0001252

Vinesh. (2014). Role of training and development in an organizational development. International Journal of Management and International Business Studies, 4(2), 213-220.

\section{Copyrights}

Copyright for this article is retained by the author(s), with first publication rights granted to the journal.

This is an open-access article distributed under the terms and conditions of the Creative Commons Attribution license (http://creativecommons.org/licenses/by/4.0/). 